\title{
Stenaptinus (Coleoptera: Carabidae: Brachininae) of Vietnam. Note 3
}

\section{Stenaptinus (Coleoptera: Carabidae: Brachininae) Въетнама. Сообщение 3}

\author{
D.N. Fedorenko \\ A.H. Федоренко
}

\begin{abstract}
A.N. Severtsov Institute of ecology and evolution, Leninsky pr. 33, Moscow 119071, Russia.
Институт проблем экологии и эволюции им. А.Н. Северцова, Российская Академия Наук, Ленинский пр-т 33, Москва 119071, Россия, E-mail: dmitri-fedorenko@yandex.ru
\end{abstract}

\begin{abstract}
KEY WORDS: Coleoptera, Carabidae, Brachininae, Stenaptinus, new synonym, Vietnam, Oriental region.
КЛЮЧЕВЫЕ СЛОВА: Coleoptera, Carabidae, Stenaptinus, новый синоним, Вьетнам, Ориентальная
\end{abstract} область.

ABSTRACT. The tripustulatus species group of the genus Stenaptinus Maindron, 1906 is briefly reviewed. It is represented by the only oligotypic species, S. occipitalis (Macleay, 1825), in Vietnam. Stenaptinus siamensis (Chaudoir, 1876), syn.n., and S. nebulosus (Chaudoir, 1876) (=formosanus (Dupuis, 1912)), syn.n., are only recognized to be similar colour morphs, and $S$. obiensis (Hrdlička, 2015) and S. talaudensis (Hrdlička, 2015) are supposed to be another colour morph, of $S$. $o$. occipitalis. Stenaptinus o. jessoensis (A. Morawitz, 1862), stat.n., S. o. indicus (Venugopal et Thomas, 2019), stat.n., and probably also $S$. o. nigerrimus Jedlička, $1935(?=S$. taclobanensis Lassalle et Schnell, 2019) are the other subspecies. Stenaptinus occipitalis and $S$. catoirei (Dejean, 1825) are supposed to be a superspecies combined, and S. catoirei, S. sobrinus (Dejean, 1826) and S. chaudoiri (Arrow, 1901) are treated as conspecific taxa, as they have the internal sacs of aedeagi very similar to each other and hardly different from that of $S$. occipitalis. Relations between $S$. $o$. occipitalis, $S$. o. indicus and $S$. catoirei sensu lato are discussed. Other synonyms established are $S$. hilaris $($ Fabricius, 1798$)=S$. devagiriensis $($ Venugopal et Thomas, 2019), syn.n., and S. catoirei (Dejean, 1825) = S. malaisei (Landin, 1955), syn.n.

РЕЗЮМЕ. Дан обзор группы tripustulatus рода Stenaptinus Maindron, 1906. Она представлена во Вьетнаме единственным олиготипическим видом - S. occipitalis (Macleay, 1825). Stenaptinus siamensis (Chaudoir, 1876), syn.n., и S. nebulosus (Chaudoir, 1876) (= formosanus (Dupuis, 1912)), syn.n., считаются не более чем сходными цветовыми формами $S$. o. occipitalis, a S. obiensis (Hrdlička, 2015) и $S$. talaudensis (Hrdlička, 2015) предположительно причислены к иной цветовой форме того же подвида. Прочие подвиды - это S. o. jessoensis (A. Morawitz, 1862), stat.n., S. o. indicus (Venugopal et Thomas,
2019), stat.n., и вероятно S. o. nigerrimus Jedlička, 1935 (? = S. taclobanensis Lassalle et Schnell, 2019). B виду крайнего сходства внутренних мешков эдеагусов S. catoirei (Dejean, 1825), S. sobrinus (Dejean, 1826) и $S$. chaudoiri (Arrow, 1901) и их мизерных отличий от такового $S$. occipitalis, первые три таксона считаются конспецифичными, и предполагается, что S. catoirei и $S$. occipitalis формируют надвидовой комплекс. Обсуждаются взаимоотношения $S$. o. occipitalis, S. o. indicus и $S$. catoirei sensu lato. Новая синонимия включает также $S$. hilaris (Fabricius, 1798) $=S$. devagiriensis (Venugopal et Thomas, 2019), syn.n., и $S$. catoirei (Dejean, 1825) = S. malaisei (Landin, 1955), syn.n.

\section{Introduction}

In this paper we review the tripustulatus species group of the genus Stenaptinus Maindron, 1906 (Brachinini, Brachininae, Carabidae) from the Oriental region, chiefly Vietnam. It is widespread in the Paleotropical realm up to Australia, being especially speciesrich and probably originates in the Afrotropical region. Out of ca. 20 Oriental species of this group, 15 were listed by Andrewes [1930] and most of the other six have been contributed to the group just recently [Jedlička, 1935; Hrdlička, 2015; Lassalle, Schnell, 2019; Venugopal, Thomas, 2019]. All of them were described based on particular colour patterns, sometimes combined with slight differences in body proportions, i.e., longer or shorter pronotum and/or elytra. These species otherwise are very similar in many characters, including male and female genitalia, while vary greatly, both individually and geographically, in body pattern, including particulars of the head, pronotum and elytra. This suggests that some species names currently recognized as valid may have come from this variation, thus

How to cite this article: Fedorenko D.N. 2021. Stenaptinus (Coleoptera: Carabidae: Brachininae) of Vietnam. Note 3 // Russian Entomol. J. Vol.30. No.3. P.252-263. doi: 10.15298/rusentj.30.3.02 
being subspecific or infrasubspecific only. Their relations are briefly discussed below.

Acronyms used are as follows: MNHN — Museum National d'Histoire Naturelle, Paris; MPSU — the Moscow Pedagogical State University; SIEE — the author's reference collection at A.N. Severtsov Institute of Ecology \& Evolution, Russian Academy of Sciences, Moscow; ZISP - Zoological Institute, Russian Academy of Sciences, St. Petersburg; ZMMU — Zoological Museum of the Moscow State University; ZSM Siberian Zoological Museum, Novosibirsk.

The following parameters and ratios (Table 2) were analyzed: maximum body length measured between apices of closed mandibles and sutural angle of elytra (BL); length of elytron, measured from the highest point of basal margin to sutural angle (EL); maximum width of elytra (EW); width of head across eyes (HW); width of pronotum between apical (PA) or basal (PB) angles; length of pronotum along median line (PL); distance between pronotal apex and level of maximum width of pronotum, measured along mid-line (PLw); maximum width of pronotum $(\mathrm{PW})$. The measurements were taken using an eyepiece micrometer, to two decimal places. The means are given in round brackets for the ratios. All labels are printed unless otherwise specified in square brackets. Data on labels of type specimens are in quotes; slash shows new line.

Male aedeagi were examined dried or with internal sac everted and maximally inflated with air and then airdried; female genitalia were examined either dried or placed in glycerin, after being boiled for two minutes or put for a day in a diluted $\mathrm{KOH}$ solution and then rinsed.

\section{Results}

\section{Stenaptinus Maindron, 1906}

The tripustulatus species group.

DIAGNOSIS. Body macropterous to apterous, variegated (Figs 1-19), often with forebody pale, sometimes entirely black or almost so. Head without or with a black patch. Elytral transverse median band mostly wide and moderately dentate at ridge 4 or 5, or 4-to-5, anteriorly and posteriorly, often clavate toward suture or in form of a large spot. Pronotum with rather sparse yet distinct coarse punctures toward apex and often also along both sides and base. Prosternum and often also propleura distinctly and more or less densely pilose in apical half in addition to several stronger setae between procoxae. Elytra subparallel-sided to much broader apically than basally, with humeri either distinct or missing, respectively. In female, tergite VII with 17-38 and sternite VIII with about ten strong yet rather short setae; sternite VIII with a narrow medio-apical sclerite [Fedorenko, 2020].

Median lobe of aedeagus (Figs 20-39) with apex flattened dorsoventrally and finely longitudinally grooved ventro-apically; internal sac symmetrical. In female, urite XI with a long median sclerotization between grooves for receipt of gonocoxites IX; these slender, very long, sparsely setulose along dorsal edges.

DESCRIPTION. Black median patch on head generally consists of posterior spot which runs on vertex and posterior half of frons, ranging from small and isolate to large, reaching pronotal apex or occupying entire neck, or extending onto clypeus and often also ontolabrum into an oblong anterior spot. Pronotum with black median stripe not or much wider apically than basally. Elytral pale pattern generally consisting of transverse median band, large to missing humeral spot, wide to imperceptible apical margin, and narrow to missing lateral margin. Antennae brown, with segments 1-4 yellowish, not contrastingly paler than the rest.

Dorsal microsculpture mostly distinct, rather coarse, consisting of very small meshes, isodiametric on head, on pronotum and on elytral ridges, longitudinal on elytral intervals, sometimes vague on elytral ridges or obliterate on pronotum.

Head sparsely punctate and pilose at posteromesal margin of eye; neck rugose.

Elytral ridges rather wide, subconvex, slightly wider to slightly narrower than intervals; these densely longitudinally carinulate, with ca. 9-12 carinules across interval 4 at middle. Setation as for the javanus-group: in general, interval 1 with multiple pores bearing short setae; these arranged in an uneven row and almost reaching apex; interval 2 with 5-6, sometimes seven, long setae; interval 5 with a long seta at base. male.

Profemur in dorsal view more or less distinctly tumid in

Sternite VII bisetose to quadrisetose in both sexes.

Median lobe of aedeagus (Figs 20-39): internal sac membranous and very gentle, more so apically, consisting of a large dorsal basal bulb and an oblong body which directly extends into an apical bulb while abruptly curved ventrad at acute to obtuse angle just before. Basal bulb barely subdivided into two short and rounded bulbs that project dorsad and laterad; apical bulb more or less developed, tapered, slightly dorsoventrally flattened toward tip, apically truncate and indistinctly bifid in dorsal view.

GEOGRAPHIC DISTRIBUTION. Throughout the Paleotropical realm east to the Australian region, and adjacent parts of the southern Palearctic subregion from Spain to Japan.

HABITATS AND HABITS. Most species of this group are rather common in open habitats at ca. $10-650 \mathrm{~m}$ altitudes and less frequent in mountains up to $1.800 \mathrm{~m}$ elevation. Adults of $S$. occipitalis (Macleay, 1825) are carnivorous polyphages [Habu, 1967] of diurnal activity in at least laboratory experiments [Frank et al., 2009], but many specimens collected in nature have been taken at light at night. Larvae of S. jessoensis (A. Morawitz, 1862) specialize in feeding on eggs of mole crickets (Orthoptera, Gryllotalpidae), such as Gryllotalpa Latreille, 1802 while survive on eggs of Neocurtilla Kirby, 1906 and Scapteriscus Scudder, 1868 under laboratory conditions [Frank et al., 2009].

COMMENTS. It follows from a comparative morphological analysis across the group that the Oriental region east of India is largely populated by the only polytypic species, $S$. occipitalis. Andrewes $[1919,1930]$ considered it to range from India and Sri Lanka to the Andamans, Myanmar, the Malay Peninsula and the Sunda Isles. He also reported this species from Hong Kong and Taiwan, while noting [Andrewes, 1931] no specimen seen from northwestern India or Indochina. Except for Hong Kong and Taiwan, this pattern largely coincides with distribution pattern of the nominotypical subspecies. In its most populations from northwestern Thailand to Sumatra, those colour morphs dominate that are defined by the elytral pale pattern consisting of rather a wide median band, narrow lateral margin, and very narrow to indistinct apical margin, with only apices of elytral costae pale. Black pronotal pattern includes lateral beads (following 
black notopleura), base, apex, and a subtriangular median stripe in between, this latter being wide, much more so apically than basally, with its sides more or less distinctly angulate at or just before the middle. The black patch on the head is well-developed, generally consisting of a large posterior spot extending into a narrower anterior spot that covers

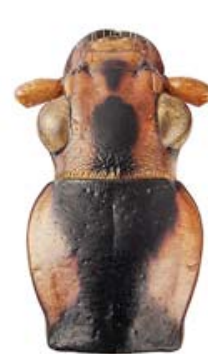

1

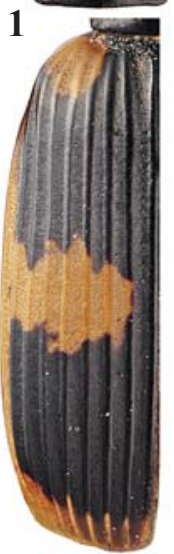

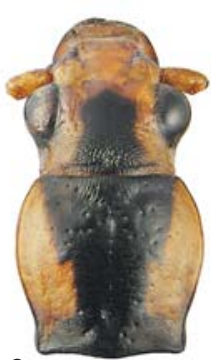

2

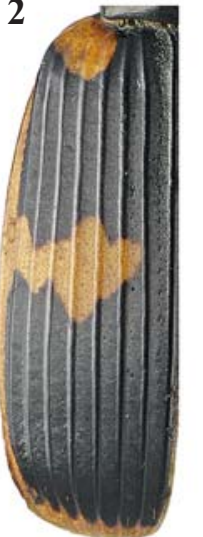

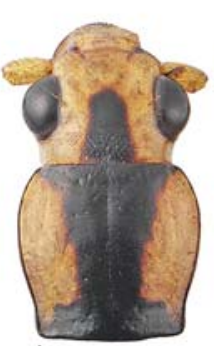

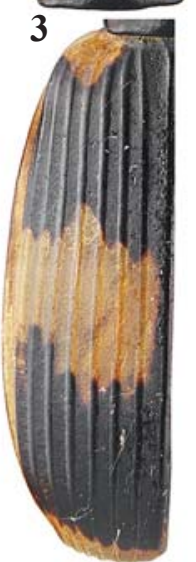

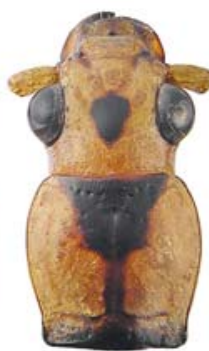


5


Figs 1-14. Variation of dorsal pattern in specimens from different localities: 1-7, 9 - Stenaptinus o. occipitalis; 8 - S. o. indicus, N Goa; $10-$ S. o. nigerrimus, Mindanao, Philippines; 11-13 - S. o. jessoensis; $14-$ S. bimaculatus, Sri lanka; 1 - Cat Tien NP, S-Vietnam; 2 - Phang Nga Pr., Thailand; 3 - Ma Da forest, S-Vietnam; 4 - Sa Kaeo Pr., Thailand; 5 - Cat Ba Is., N-Vietnam; 6-7 - Cambodia; 9 - Java; 11 - Phia Oac NP, N-Vietnam; 12 - Thai Nguen; 13 - Gansu, China.

Рис. 1-14. Изменчивость окраски верха у особей из разных местонахождений: 1-7, 9 - Stenaptinus o. occipitalis; 8 - S. o. indicus, Северный Гоа; $10-S$. o. nigerrimus, Филиппины, Минданао; 11-13 - S. o. jessoensis; 14 - S. bimaculatus, Шриланка; 1 - Южн. Вьетнам, нац. парк Катьен; 2 - Таиланд, пров. Пхангнга; 3 - Южн. Вьетнам, лес Мада; 4 - Таиланд, пров. Са Каео; 5 - Сев. Вьетнам, о-в Катба; 6-7 - Камбоджа; 9 - Ява; 11 - Сев. Вьетнам, нац. парк Фиаок; 12 - там же, Тайнгуен; 13 - Китай, Ганьсу. 
the clypeus and anterior half of the frons (Figs 1,9). Variants mostly include pale lateral margins of the elytra, which are absent from basal half, and/or the entirely black pronotum, except for a minute, oblong, usually double, pale sublateral spot. The anterior capital spots is not seldom absent or separated from the posterior spot, the latter ranging considerably in size, from slender, only touching the pronotal apex just medially, to occupying the entire neck.

In many adults from Java and the island of Bali, the body tends to be nearly black, with pale colour underdeveloped on the head, absent from the pronotum or almost so, and reduced to a small elytral humeral spot and to a very narrow, sometimes vague, median transverse band separated from the lateral margin (Fig. 9) - see also Fig. 498 c, d in Habu [1967]. Stenaptinus talaudensis (Hrdlička, 2015), S. obiensis (Hrdlička, 2015), S. nigerrimus Jedlička, 1935 and $S$. taclobanensis Lassalle et Schnell, 2019 are certain to be in course of this evolutionary trend so that the former two taxa are only distinctive from $S$. o. occipitalis in having entirely black elytra, and the latter two also in the anteriorly truncate posterior spot on the head, combined with black pronotum. I see no sufficient differences between $S$. nigerrimus and $S$. taclobanensis, and aedeagus examined in two males of the former species $\left(2 \sigma^{7} \sigma^{\top}, 0\right.$, Philippines, Kabanglasan, Bukidnon, Mindanao, VIII.2014, local collector) is much more similar to that of $S$. taclobanensis than of $S$. nigerrimus, as figured in Lassalle and Schnell [2019], in shape. This means rather high variation range of this character in the taxa compared, thereby deleting their distinctive features. In sum, my comparison between the taxa discussed invites me to provisionally consider $S$. nigerrimus as an eastern, insular, poorly differentiated subspecies of $S$. occipitalis while $S$. talaudensis and $S$. obiensis as infrasubspecific names, colour morphs, i.e., synonyms, of S. o. occipitalis rather than of S. o. nigerrimus.

Specimens from Sumatra and, especially, Java are not or hardly different from Indian ones of which many (Fig. 8) have the pale median band larger (longer) and separate from lateral margin of the elytron, the posterior capital spot wider and often slightly concave ( $v s$. truncate or slightly convex) at anterior margin, and the pronotum mostly black. These specimens belong to $S$. indicus (Venugopal et Thomas, 2019), described just recently based on its differences from $S$. occipitalis sensu Venugopal et Thomas, 2019. This latter is certain to be different from $S$. occipitalis because Figure $2 \mathrm{E}$ in Venugopal et Thomas [2019] shows a specimen of $S$. jessoensis from China, misidentified by the authors as a 'verified specimen of $S$. occipitalis'. This confusion also obscures all the records of 'S. occipitalis' in Tamil Nadu and Kerala, southern India, listed in that paper.

On the other hand, $S$. indicus has the internal sac of aedeagus reduced much in size except at the base. This peculiarity makes differences between $S$. indicus and $S$. occipitalis (compare Figs 27-28 with Figs 20-25, 29-32) more prominent than those between $S$. occipitalis and $S$. catoirei (Dejean, 1825), which points rather to separate species or subspecies status of $S$. indicus and $S$. occipitalis. The latter alternative is more likely because the internal sac with an underdeveloped body as an occasional variation has also been observed in specimens of S. o. occipitalis from northern Thailand.

An opposite evolutionary trend brought most adults from Indochina into being distinctly paler in colour than those discussed above. As a result, the specimens from Thailand (except in the north), Laos, Cambodia and Vietnam have the head generally pale but an oblong black spot between the eyes; pronotal lateral spots are large and reach the lateral edges; and black elytral pattern is isolated, consisting of two transverse bands, anterior and posterior, which are narrowly connected along the suture. This paler form was described under the names $S$. siamensis (Chaudoir, 1876) and S. nebulosus (Chaudoir, 1876) of which the latter additionally had the pronotum black along the base and along the apex only. This pale form prevails throughout the region discussed, with melanistic specimens being less frequent there while common in Taiwan and in the southernmost Japan. These specimens were assigned [Dupuis, 1913, 1914] to S. fuscicollis var. formosanus (Dupuis, 1912) as distinctive among the others in having pale pattern consisting of a minute sublateral spot on the pronotum and a small median spot, along with a normally developed humeral spot, on the elytron.

Stenaptinus jessoensis is here recognized as hardly more than a northeastern subspecies of $S$. occipitalis. It is rather well-defined morphologically, with body pattern less varying than in the nominotypical subspecies. Stenaptinus o. jessoensis and S. o. occipitalis, especially its forma siamensis, are otherwise very similar in most characters, including male genitalia (Figs 20-25), so that black capital patch of particular shape only allows diagnosing their some specimens; vicariant distribution patterns of the two subspecies serve for the purpose, too.

The other Oriental species are Indian in distribution, some of them ranging east to Myanmar. Among species with distinct elytral humeri and a contrastingly bicoloured head, $S$. bimaculatus (Linnaeus, 1771) and S. tripustulatus (Fabricius, 1792), are confined to southern India. Very distinctive internal sac of aedeagus (Figs 26, 33 ) and a peculiar body pattern, the latter due to the presence of a very large elytral pale spot (Fig. 14), justify species status of S. bimaculatus, but $S$. tripustulatus still remains enigmatic. It is similar to $S$. bimaculatus in many points except that the elytral median band is narrow, clavate toward the suture, with lateral margin pale ( $v s$. black in the examined specimens of S. bimaculatus), which is more characteristic of S. o. occipitalis. Having no specimens other than two digital images, including that of the holotype (J. Banks Collection, British Museum of Natural History, London: flickr.com/photos/nhm beetle.id/ 29775838283), of $S$. tripustulatus seen, I failed to deduce whether S. tripustulatus is separate species or a colour morph of $S$. bimaculatus, or a local colour morph of $S$. occipitalis which lacks the anterior black spot on the head. The latter choice is more likely because $S$. tripustulatus and specimens of $S$. o. occipitalis from northern Thailand are very similar not only in body pattern, but also in fairly short elytra (see below). On the other hand, Andrewes [1921, 1924b,c] doubted Siamese origin of $S$. tripustulatus by appealing to his experience of seeing no specimens of this species from regions beyond southern and Central India.

The following species of the group are distinctive in having the head and the pronotum constantly pale, yellow to deep red, with pronotal base and apex more or less infuscated in some of them (Figs 15-19). These are: S. catoirei, S. sobrinus (Dejean, 1826), including $S$. hilaris auct. (non Fabricius, 1798), S. chaudoiri Arrow, 1901, and S. malaisei (Landin, 1955). Their distinctive features only include details of the elytral pale pattern, such as the combination of distinct humeral spot and wide apical margin in the first species; minute or absent humeral spot, combined with pronotal base and/or apex either infuscated (S. hilaris auct.) or not, in the second; and rather a narrow apical margin, coupled with more or less widely brown lateral margins of the pronotum, in $S$. chaudoiri. All these differences seem to be slight, and transi- 
tional patterns do exist. For instance I have failed to discriminate between seven specimens of $S$. catoirei and S. chaudoiri from Nepal, including the holotype of the latter (Fig. 1F in Venugopal and Thomas [2019]). These have the elytral transverse median band more or less wide, reaching lateral margin or not, and pronotal pattern varying between those characteristic of either S. catoirei or S. chaudoiri. Besides, one female specimen (Fig. 17) has the pronotum not only distinctly brownish along sides towards the base, but also widely brownish along the base except at middle, as is characteristic of $S$. hilaris auct. Aedeagi, including internal sacs, are hardly if at all different from one another in all specimens determinable as either $S$. catoirei or S. sobrinus, or S. hilaris auct., or $S$. chaudoiri (Figs 31-32, 35). This makes me only consider all the names conspecific, probably particular colour morphs. Stenaptinus malaisei is most likely to be the same, since all features indicated in the original description are within variation range of $S$. o. catoirei s. lato, even though Landin [1955] stressed species status of his species.

Stenaptinus catoirei is not unlikely to be conspecific with S. africanus (Dejean, 1825) and/or S. arabicus Arrow, 1901, which are known to range combined in North Africa to Iran, thus having distribution pattern vicariant to that of $S$. catoirei s. lato. They are only distinguished from 'S. sobrinus' or $S$. hilaris auct., respectively, by pale lateral margin generally absent from the elytra, and from $S$. catoirei s.str. by having no elytral humeral spot. But the body pattern has been found [Britton, 1948; Felix, 2009; Felix et al., 2012] to vary consid- erably between local populations of these species, examined from Morocco to India. For the reason, Bedel [1914] noted similarity between $S$. africanus and $S$. desbordesi, Britton [1948] recognized $S$. africanus and S. arabicus as conspecific, and Lorenz [2005] listed S. arabicus and S. persicus as synonymous with $S$. africanus.

Another species, S. lineifrons (Chaudoir, 1850) was described based on more than one specimen, which follows from the variation range 7-7.5 lines indicated for BL in the original description. Accordingly the specimen termed 'holotype' [Venugopal, Thomas, 2019: Fig. 1 I] should be referred to as a syntype. This species is somewhat intermediate between those of $S$. o. occipitalis and S. o. catoirei in body pattern, while being much closer to the latter. The pronotum is coloured same as that of $S$. catoirei, but the head and the elytra are similar to those of $S$. o. occipitalis, except only that the forebody is pale coloured but dark anterior spot on the head. Greater similarity between $S$. lineifrons and S. o. occipitalis may suggest their synonymy (yet, formal synonymy is not proposed here, since no male specimen of $S$. lineifrons has been dissected).

Another probable member of the group, S. assamensis (Chaudoir, 1876), is distinctive in the combination of distinct elytral humeri, pronotal pattern much like that of $S$. hilaris, and 'Siam' indicated as the type locality. Without seeing the type, Arrow [1901] synonymized S. assamensis with the West African species S. palmarum (Chaudoir, 1876), even though Chaudoir [1876] had mentioned in the descriptions,



15

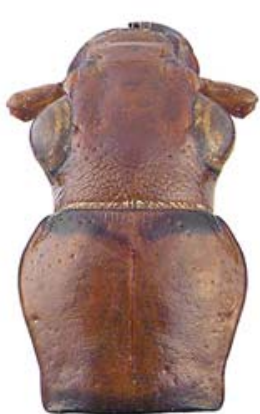

16

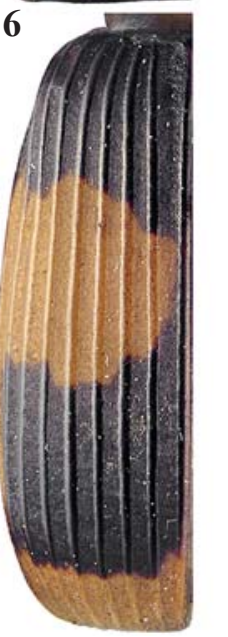

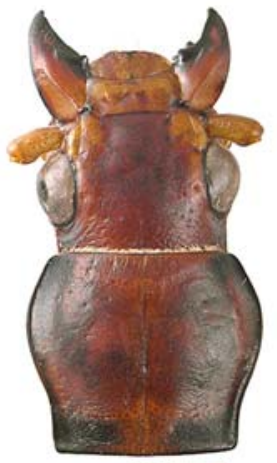

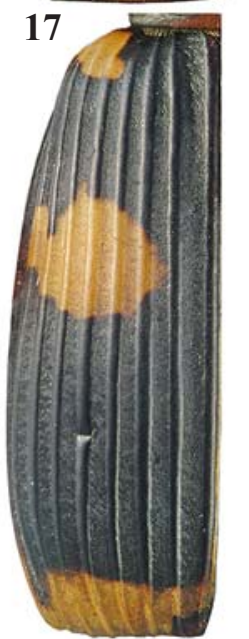

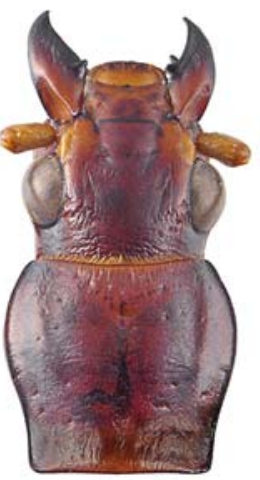

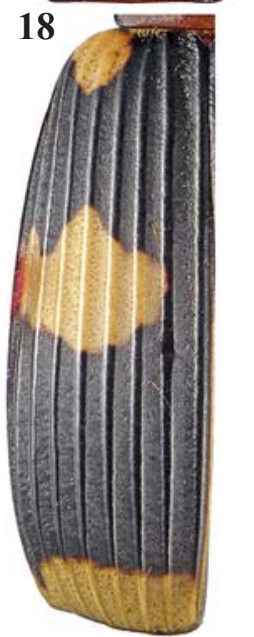

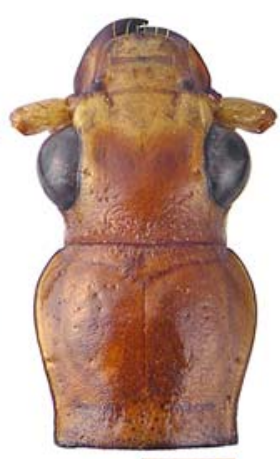

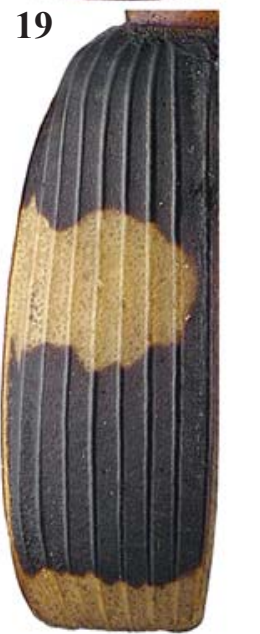

Figs 15-19. Variation of dorsal pattern in specimens of Stenaptinus catoirei from different localities: 15-16 - Manapakkam, Chennai, India; 17- env. Katmandu, Nepal; 18 - Pokhara, Nepal; 19 - Rajasthan, India.

Рис. 15-19. Изменчивость окраски верха у особей Stenaptinus catoirei из разных местонахождений: 15-16 - Индия, Ченнай, Манапаккэм; 17- Непал, окр. Катманду; 18 - там же, Покхара; 19 - Индия, Раджастхан. 
as well as in the key, that $S$. assamensis had, while $S$. palmarum had no, black spot on the head. The fact that these character states graduate into one another in no species of the group except $S$. hilaris, combined with unproved falsity of 'Siam' as the type locality of $S$. assamensis, may suggests this synonymy being wrong. If true, the elytron with a strongly dentate median fascia only discriminates $S$. assamensis from S. o. occipitalis forma siamensis.

The remaining species have no elytral humeri and supposedly also wings, which peculiarity may explain their limited distribution patterns. These appears to be $S$. infantulus Bates, 1892 and $S$. nanodes Bates, 1892, the latter of which seems to be closer to $S$. o. jessoensis. Another species, S. hilaris (Fabricius, 1798) $=S$. discicollis $($ Dejean, 1825) $=$ $S$. affinis (Dejean, 1825) has recently been demonstrated [Venugopal, Thomas, 2019] to be not conspecific with $S$. sobrinus (= hilaris auct.). It is hardly different from $S$. devagiriensis (Venugopal et Thomas, 2019) in virtually all characters, including body shape, proportions and pattern, notably pronotal one, and at least two of totally six diagnostic features mentioned in the description of the latter species, the entirely yellow head and the laterally black pronotum, are inconsistent with what is indeed observed. In particular, the head is entirely pale also in S. affinis and Fig. 3C in Venugopal et Thomas [2019] shows pronotal lateral margin widely black in the illustrated specimen of $S$. discicollis. Furthermore, it follows from comparison between Fig. 4A and Figs 3A-E [ibid.] that pale apical margin of the elytron varies considerably in width, while being barely narrower in $S$. devagiriensis than in $S$. hilaris. The remaining three distinctive features, (1) smaller humeral spots of the elytra and (2) the pronotum glabrous and shiny, (3) with deep median line, do not seem sufficient to maintain species status of $S$. devagiriensis. For the reason synonymy $S$. hilaris (Fabricius, 1798) $=S$. devagiriensis (Venugopal et Thomas, 2019), syn.n., is proposed here. It is worthy of note also that $S$. hilaris $(=S$. devagiriensis) has hitherto been known from very few exact localities in Tamil Nadu only, therefore all or at least great majority of the former records of $S$. hilaris in India except Tamil Nadu should be referred to as $S$. sobrinus (= S. hilaris auct.), with the species range of $S$. hilaris as described by Venugopal and Thomas [2019] being restricted accordingly.

Relations between of $S$. catoirei s. lato, S. o. occipitalis and $S$. o. indicus are interesting yet not quite clear. The range of the former and the range of the latter two combined widely overlap in India where the respective colour morphs (with the forebody either pale or contrastingly bicoloured) have been found to live syntopically, and some slight differences between the taxa has also been observed. In particular, the elytra are barely shorter in $S$. catoirei s. lato (EL/EW 1.39-1.52, mean $1.45, \mathrm{n}=19$ ) than in $S$. o. occipitalis and $S$. o. indicus combined (EL/EW 1.48-70, mean 1.57, $\mathrm{n}=21$; insular population not counting). On the other hand, S. o. indicus (Figs 20-21) has rather distinctive internal sac of aedeagus, whereas it is nearly identical in $S$. catoirei s. lato and S. o. occipitalis (Figs 20-25, 29-32).

Out of the forms intermediate between $S$. catoirei s. lato and $S$. occipitalis, $S$. lineifrons may be the first, and the second has been found in Mae Hong Son Province, northern Thailand. It is only different from typical $S$. o. occipitalis in having the elytra shorter (EL/EW 1.40-1.50, mean 1.45, $\mathrm{n}=5$ ) and the apical setae on female tergite VIII (Tab. 1) are more in number, 24-30 in five of totally six specimens examined (vs. 17-23 setae, as is usual in S. o. occipitalis). This characters combination, including EL/EW value and number of the apical setae being peculiar to $S$. catoirei $\mathrm{s}$. lato rather than to $S$. o. occipitalis, may have come from secondary intergradation of the taxa. An assumption that $S$. $o$. indicus substitutes for the latter in India suggests that $S$. occipitalis and $S$. catoirei s. lato combined may be a superspecies, with intergradation zone being in northern Thailand and the adjacent lands.

This superspecies could have formed by interaction of two, formerly isolated, populations groups, either very close species or well differentiated subspecies of an ancestral species, western 'sobrinus - africanus' and eastern 'occipitalis'. It was perhaps aridization process in the past that induced the western subspecies to expand its range eastward and probably also caused or facilitate differentiation of the eastern species into $S$. o. occipitalis and $S$. $o$. indicus. As these two intergraded with $S$. 'sobrinus africanus', populations of transitional adult characters formed, which color morphs sobrinus, catoirei, chaudoiri and perhaps lineifrons could have evolved from. Because this scenario is only speculation, I leave $S$. catoirei and $S$. occipitalis as separate species until new data to the contrary are obtained from molecular studies or immature stages are examined, or both.

\section{1a. Stenaptinus occipitalis occipitalis (Macleay, 1825)} Figs 1-7, 9, 20-23, 29-30, 36, 38-39.

Macleay, 1825: 28 (Aptinus; Java); Arrow, 1901: 204 (Pheropsophus); Andrewes, 1919: 168; 1930: 274; 1931: 437; 1933: 365; Habu, 1967: 288; 1984: 122; Hrdlička, 2017: 480. - fuscicollis Dejean, 1825: (Brachinus; Java); Chaudoir, 1876: 37 (Pheropsophus); Bates, 1886: 200; 1892: 391. — ambiguus Dejean, 1825: (Brachinus; Java); Chaudoir, 1876: 37 (Ph. fuscicollis var.). intrerruptus Dejean, 1825: (Brachinus; Java); Chaudoir, 1876: 37 (Ph. fuscicollis var.). — quadripustulatus Chaudoir, 1843: 706 (Pheropsophus; Java); 1876: 37 (Ph. fuscicollis var.). - javanus: Chaudoir, 1876: 42 (part.); Jedlička, 1964: 532 (part.). — marginalis: Schmidt-Göbel, 1846: 74 (Brachinus; Birma); Bates, 1892: 393 (Pheropsophus). — stabilis Andrewes, 1924a: 470.

- siamensis Chaudoir, 1876: 29 (Pheropsophus; 'le royame de Siam'); Bates, 1889: 281; Andrewes, 1930: 276, syn.n. - nebulosus Chaudoir, 1876: 27 (Pheropsophus; 'Siam'); Andrewes, 1921: 149; 1930: 276; Hrdlička, 2017: 480, syn.n. — formosanus Dupuis, 1912: 322; 1913: 81; 1914: 418 (Ph. fuscicollis var.; Taiwan); Hrdlička, 2017: 480. Bates, 1889: 281 (Pheropsophus); Lesne, 1904: 79; Andrewes, 1921: 149; 1923: 43; — bimaculatus: Lesne, 1904: 79 .

MATERIAL. Holotype + of Pheropsophus siamensis (MNHN, digital images), with two handwritten labels: 'type' and 'siamensis/ Chaud./ Siam/ Castelnau', and printed label 'Ex Musaeo/ Chaudoir'. Additional material includes 89 specimens: + (SIEE), Thailand, Phang Nga Prov., Phang Nga Bay, Ko Yao Noi Is., 27.VI7.VII.2017 (D. Khaydarov \& I. Malykh); ○', 9 (SIEE), Mae Hong Son Province, env. Pai, $19^{\circ} 14^{\prime} 14^{\prime \prime} \mathrm{N} / 98^{\circ} 28^{\prime} 55^{\prime \prime} \mathrm{E}, \mathrm{h}=600 \mathrm{~m}, 26 . \mathrm{IV}-$ 9.V.2013 (I. Melnik); $60^{\top} \sigma^{\top}, 4$ 오, same data, except for $19^{\circ} 27^{\prime} 23^{\prime \prime} \mathrm{N} /$ $98^{\circ} 26^{\prime} 43^{\prime \prime} \mathrm{E}, \mathrm{h}=500 \mathrm{~m}$ or $19^{\circ} 27^{\prime} 42^{\prime \prime} \mathrm{N} / 98^{\circ} 27^{\prime} 46^{\prime \prime} \mathrm{E}-19^{\circ} 22^{\prime} \mathrm{N} /$ $98^{\circ} 30^{\prime} 29^{\prime \prime}, \mathrm{h}=600 \mathrm{~m} ; 2 \mathrm{\sigma}^{7} \mathrm{\sigma}^{7}$ (MPSU), same locality, $19^{\circ} 14^{\prime} 14^{\prime \prime} \mathrm{N} /$ $98^{\circ} 28^{\prime} 55^{\prime \prime} \mathrm{E}, \mathrm{h}=600 \mathrm{~m}, 22$.II-7.III.2010 (O.A. Mosolov); 9 (SIEE), Chiang Rai Province, env. Mae Suai, 19³9'16"N/ 99॰32'54"E, $\mathrm{h}=450 \mathrm{~m}, 10-11$.V.2013 (I. Melnik); 36 spms. (ZSM), Prov. Nakhon Ratchasima (Korat), Saeng Sang, Lam Sae Dam, Natn. Park Tha Plan, h=250 m, $14^{\circ} 16^{\prime} 40^{\prime \prime} \mathrm{N} / 102^{\circ} 25^{\prime} 28.5^{\prime \prime}$ E, 7-8.VI.2010, 24-30.VII.2012, 7-12.VIII.2013 (A.V. Korshunov); 7 spms. (ZSM), Nong Bun Nak, marginal deciduous forest, $\mathrm{h}=200 \mathrm{~m}, 14^{\circ} 41^{\prime} 25^{\prime \prime} \mathrm{N}$, $102^{\circ} 27^{\prime} 45.7^{\prime \prime} \mathrm{E}, 19-24$.V.2010 and 26-31.X.2011 (A.V. Korshunov); 오( SIEE), same locality, $\mathrm{h}=240 \mathrm{~m}, 1^{\circ} 41.3^{\prime} \mathrm{N}, 102^{\circ} 27.3^{\prime} \mathrm{E}$, 24.V.2010 (V.K. Zinchenko); O' (SIEE), Sa Kaeo Prov., Ta Phraya Distr., La Lu Natn. Park, $14^{\circ} 02^{\prime} 2^{\prime \prime N}$, 102 $34^{\prime} 5.6^{\prime \prime} \mathrm{E}, \mathrm{h}=130 \mathrm{~m}$, at light, 16.V.2010 (V.K. Zinchenko); $\sigma^{7}$ (SIEE), Laos, Prov. Ventiane, env. Van Vieng, $18^{\circ} 55^{\prime} 12^{\prime \prime} \mathrm{N} / 102^{\circ} 26^{\prime} \mathrm{E}, \mathrm{h} \sim 230 \mathrm{~m}$, at light, 7-

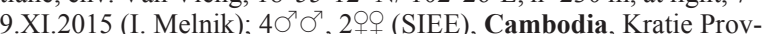
ince, $7 \mathrm{~km}$ S of Kratie, Mekong River, Prey Resey vill., 5-6.XI.2013 
Table 1. Number of apical setae in abdominal tergite VIII in female. Таблица 1. Количество апикальных хет на VIII тергите самки.

\begin{tabular}{c|c|c}
\hline Species : locality & $\mathbf{n}$ & number of apical setae \\
\hline o. occipitalis: Vietnam, Cambodia, Thailand & 9 & $17-22$ \\
Sumatra & 2 & $17-22$ \\
indicus: India & 3 & $20-23$ \\
N-Thailand (Mae Hong Son) & $\mathbf{6}$ & $\mathbf{2 1 - 3 0}$ \\
catoirei: Nepal & 3 & $24-37$ \\
$\quad$ India (Rajasthan) & 2 & 28 \\
$\quad$ Pakistan & 1 & 29 \\
o. jessoensis: China & 2 & $28-30$ \\
NE-Vietnam & 2 & $\sim 35$ \\
\hline
\end{tabular}

(A. Kompantsev); O' (MPSU), Vietnam, Hanoi, 5.XII.1989 (Yu. Zaitsev); $O^{7}$ (MPSU), $160 \mathrm{~km}$ NNW of Hanoi, env. Na Hang, 26.V14.VI.1996 (A. Napolov); 2 우 (SIEE), Hoa Binh Prov., 1.4 km WSW of Mai Chau, Na Phon Vill., 20 $0^{\circ} 39^{\prime} 20^{\prime \prime} \mathrm{N} / 105^{\circ} 03^{\prime} 54^{\prime \prime} \mathrm{E}$, bamboo forest, 21-24.IV.2019 (F. Martynovchenko); + (SIEE), Cat Ba Is. E of Hai Phong, Natn. Park, $\sim 10 \mathrm{~km}$ of Cat Ba City, $20^{\circ} 47^{\prime} 56^{\prime \prime} \mathrm{N} / 106^{\circ} 59^{\prime} 47^{\prime \prime} \mathrm{E}$, at light, 10-24.X.2011 (D. Fedorenko); $\mathrm{O}^{7}$, prov. Quang Binh Prov., Minh Hoa Distr., env. Yen Hop, 1213.IV.1999 (A. Devyatkin); O (MPSU), same locality, Ke Bang National Park, 27.IV.1999 (S. Kruskop); 2 우 (SIEE), Ha Tinh Province, Ke Go Nature Reserve, $18^{\circ} 06^{\prime} 30^{\prime \prime} \mathrm{N} / 106^{\circ} 01^{\prime} \mathrm{E}$, env. Mui Tru Station, h=40 m, 7-14.V.2015 (A. Abramov); $20^{7} 0^{7}, 2+0$ (SIEE), Dongnai Province, Cat Tien National Park, $11^{\circ} 25^{\prime} 18^{\prime \prime} \mathrm{N}$ / $107^{\circ} 25^{\prime} 44^{\prime \prime} \mathrm{E}$, at light HQL-450, 18-25.X.2004 and 30.V.2005 (D. Fedorenko); $\sigma^{7}, \sim 70 \mathrm{~km}$ NE of Saigon, Ma Da forest, 18-19.VI.1990 (N. Belyaeva); $\sigma^{7}$ (MPSU), env. Ho Shi Minh City, IV.1986 (SIEE expedition); $30^{7} 0^{7}, 3$ 오 (SIEE), Indonesia, Sumatra, W Sumatra Province, $\sim 3 \mathrm{~km}$ WSW of Bukittinggi, $0^{\circ} 18^{\prime} 26^{\prime \prime} \mathrm{S} / 100^{\circ} 20^{\prime} 32^{\prime \prime} \mathrm{E}$,

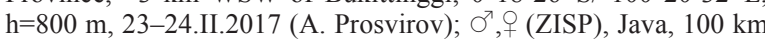
of Jakarta, Mt. Pangrango, 1000 m, 9-14.XI.1999 (A.V.Gorochov); $\sigma^{7}$ (ZSM), Bali Is, Ubud, 11-17.II.2011 (Kamskov). — Genitalia examined in 20 males and three females.

DIAGNOSIS. Head, pronotum and elytra bicoloured; capital black patch often consisting of separate or fused anterior and posterior spots; pronotum with black median stripe triangular, sometimes entirely black. Pronotum subcordate, almost subquadrate, broadest 1/3-2/5 from apex; its sides less rounded and less sinuate in front of basal angles than in S. o. jessoensis. Elytra slightly longer and more parallel-sided; ridges subconvex and rather wide, slightly narrower to slightly wider than intervals; these with very fine and dense longitudinal carinules.

REDESCRIPTION. Body macropterous. BL $12.3-18 \mathrm{~mm}$. Dorsal pattern varying (Figs 1-7, 9): elytral pale pattern mostly includes transverse median band laterally fused to a narrow lateral margin that extends into a moderately wide apical margin; sometimes (especially in populations from the Sunda Isles) lateral margin black and/or apical margin reduced to pale apices of elytral costae or totally.

Pronotum subcordate, as wide as or barely wider than long, broadest at or just before middle, with sides subsinuate a fifth from base and rounded in front. Base slightly wider than apex, both truncate; sometimes basal margin bisinuate, more (Fig. 2) or less convex medially. Basal angles mostly blunt, right or slightly obtuse, sometimes slightly acute and rather pointed; apical angles adherent to neck, obtuse, blunt or rounded. Lateral bead and groove fine and entire.
Elytra subrectangular, with rounded yet distinct humeri, not or barely broader apically than basally.

Abdomen: Tergite VII in female with rather sparse apical setae, 28-35 in number (Table 1).

Aedeagus (Figs 20-23, 29-30, 36, 38-39): internal sac with the body well-developed, dorsal basal bulb large, projecting both laterad and dorsad, not or indistinctly subdivided into two large and rounded lateral bulbs so that basal margin in dorso-apical view is straight or almost so; apical bulb at a slightly acute angle with the body.

GEOGRAPHIC DISTRIBUTION. Indochina (except for northeastern Vietnam), Taiwan, southern Japan (Ryukius), Malay Peninsula, Sunda Isles (Sumatra, Java, Bali; no records in Borneo).

COMMENTS. Pale specimens (forma siamensis and forma nebulosus) are much more frequent than darker coloured ones in most populations of the species from Indochina, except in the northernmost and probably also westernmost parts of the Peninsula. Differences between them are too slight and inconstant and thence insufficient to maintain species or subspecies status for both.

\section{[1b. Stenaptinus occipitalis indicus}

(Venugopal et Thomas, 2019), stat.n.]

$$
\text { Figs 8, 27-28, } 34 .
$$

Venugopal et Thomas, 2019: 86 (Pheropsophus; Kerala, India). - ?nigricollis Arrow, 1901: 203 (Pheropsophus; Bangalore, SIndia). - occipitalis auct. (part).

$40^{7} 0^{7}, 2$ 우 (SIEE), India, N Goa State, Ashvem Beach Area, 24.I-26.III.2013 (A. Sokolov); O (ZSM), Calangute, nr. Hotel Vilage Royale, carrion traps, $\mathrm{h}=9 \mathrm{~m}, 15.54^{\circ} \mathrm{N} / 73.77^{\circ} \mathrm{E}, 2-3 . \mathrm{XI} .2013$ (V.K. Zinchenko); 3 spms. (ZSM), Rajasthan, nr. Bharatpur, Keoladeo National Park, Ghana Bird Sanctuary, 10.XI.1969 (A. Maksimov); + (MPSU), Calcutta. — Genitalia examined in three males.

DIAGNOSIS. As for $S$. o. occipitalis except slightly different body pattern (Fig. 8): capital black patch mostly large, consisting of anterior and posterior spots, the former small to large, the latter wide, quadrate, anteriorly truncate or slightly concave, with distinct angles. Pronotum mostly entirely black or with very small, oblong, double pale spot on each side. Elytra black, with pale humeral spot, median band not reaching lateral margin and pale apices of elytral costae. Aedeagus with distinctive internal sac.

REDESCRIPTION. Unnecessary except as follows: Body macropterous, BL 15.2-17.7 mm. Posterior capital spot mod- 


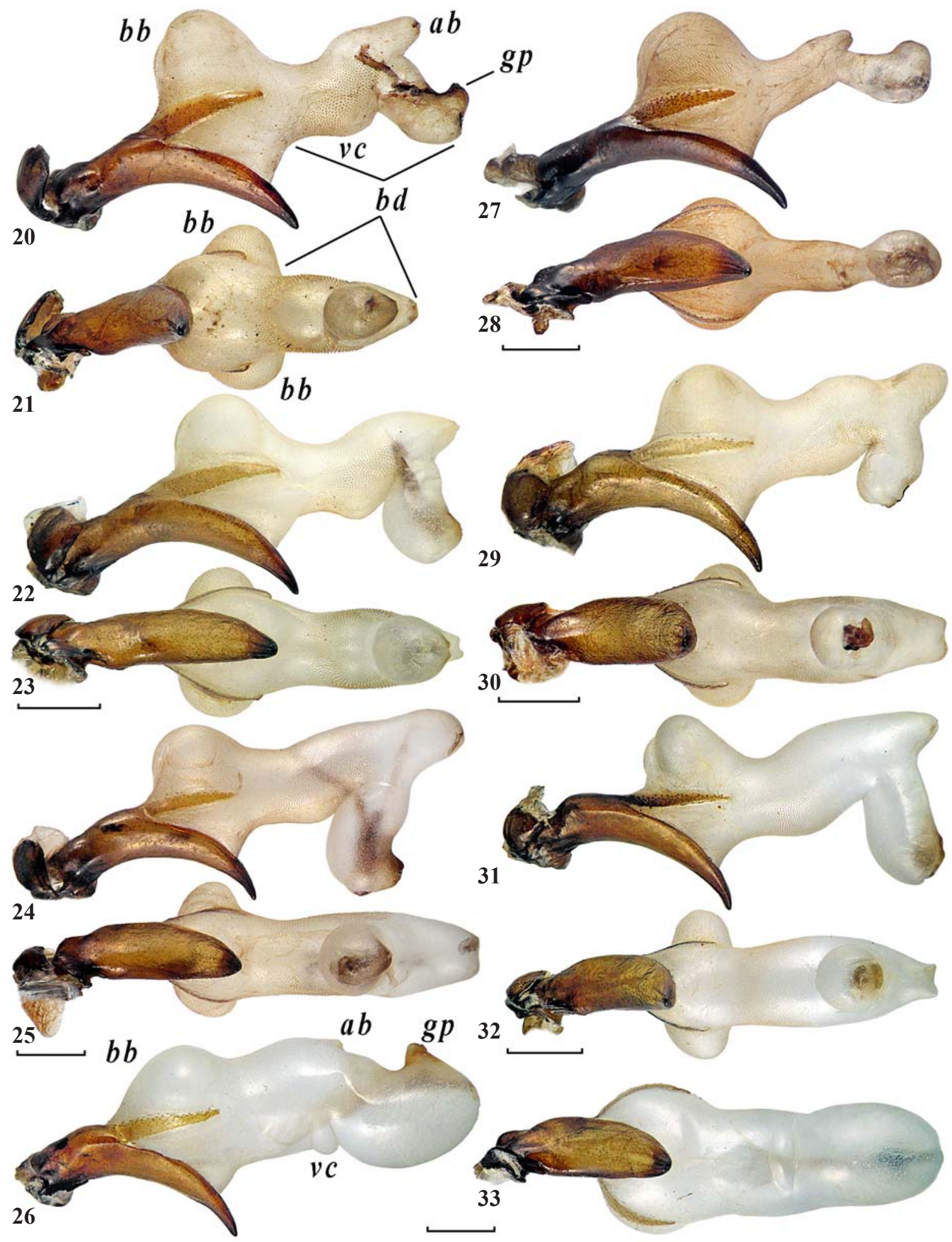

Figs 20-33. Median lobe of aedeagus with everted and inflated internal sac: 20-23, 29-30 - Stenaptinus o. occipitalis; 24-25 - S. o. jessoensis; 26, 33 - S. bimaculatus; 27-28 - S. o. indicus; 31-32 - S. catoirei; 20, 22, 24, 26, 27, 29, 31 - left aspect; 21, 23, 25, 28, 30, 32-33 - ventroapical aspect; $\boldsymbol{a} \boldsymbol{b}$ - apical bulb; $\boldsymbol{b} \boldsymbol{b}$ - basal bulb; $\boldsymbol{b} \boldsymbol{d}$ - body of internal sac; $\boldsymbol{g} \boldsymbol{p}$ - gonopore; $\boldsymbol{v}$ - ventral convexity. Scale bars: $1 \mathrm{~mm}$.

Рис. 20-33. Средняя доля эдеагуса с вывернутым и надутым внутренним мешком: 20-23, 29-30 - Stenaptinus o. occipitalis; 24-25 - S. o. jessoensis; 26, 33 - S. bimaculatus; 27-28 - S. o. indicus; 31-32 - S. catoirei; 20, 22, 24, 26, 27, 29,31 - слева; 21, 23, 25, 28, 30, 32-33 вентро-апикально; $\boldsymbol{a} \boldsymbol{b}$ - апикальный пузырь; $\boldsymbol{b} \boldsymbol{b}$ - базальный пузырь; $\boldsymbol{b} \boldsymbol{d}$ - тело внутреннего мешка; $\boldsymbol{g} \boldsymbol{p}$ - гонопор; $\boldsymbol{v}$ - вентральная выпуклость. Масштаб: 1 мм. 
erately wide to occupying entire neck; anterior spot large, extended onto labrum, to small, only touching posterior spot and clypeus. Pronotal pale spots mostly very small and double, sometimes divided into two minute spots, or large yet separated from lateral margin.

Abdomen: Tergite VII in female with 20-23 apical setae (Table 1).

Aedeagus (Figs 27-28, 34) as for S. o. occipitalis except that the body of the internal sac is reduced much in size, with apical bulb being at obtuse angle with the body.

GEOGRAPHIC DISTRIBUTION. India and probably Sri Lanka; ?Andaman Islands.

COMMENTS. The are no pale lateral margins of the elytra in all specimens examined, which may be due to very limited material. This feature is deemed to be characteristic of this subspecies, while being observed also in some specimens of $S$. o. occipitalis from Sumatra.

A senior synonym of the subspecies appears to be $S$. $o$. nigricollis (Arrow, 1901) which supposedly represents its paler colour morph defined by extensive pale pattern on the head and very large transverse median band on the elytron.

\section{1c. Stenaptinus occipitalis jessoensis \\ (A. Morawitz, 1862), stat.n.}

Figs 11-13, 24-25, 37.

Morawitz, 1862: 238 (Pheropsophus; Hakodate); Chaudoir, 1876 35; Andrewes, 1930: 273; Habu, 1967: 284; 1984: 120; Hrdlička, 2017: 480. — occipitalis: Venugopal et Thomas, 2019: 76, 78.

MATERIAL. 2 ㅇ (ZISP, MPSU), Japan, Chiba Pref., Ojagake, 14.III.1982 (S. Morita); $O^{7}$,, (SIEE), China, Jiangxi Prov., $10 \mathrm{~km}$ NE of Jingan, $\mathrm{h}=150-200 \mathrm{~m}, 29 . \mathrm{V} .2009$ (I. Ovsyannikov); $20^{7} \sigma^{7}$, , Gansu Prov., Lupan Mts, $10 \mathrm{~km}$ W of Shangguan, $35^{\circ} 03^{\prime} \mathrm{N}, 106^{\circ} 29^{\prime} \mathrm{E}$, VI.2005 (V. Siniaev team); + , Sichuan, Xiling Mts., 6.VIII.1996 (D. Fedorenko); (SIEE); Vietnam, $40 \mathrm{~km} \mathrm{~W}$ of Cao Bang, Phia Oac Mt., E Slope, $h=1600-1800 \mathrm{~m}, 22^{\circ} 36^{\prime} 237^{\prime \prime} \mathrm{N} / 105^{\circ} 52^{\prime} 0^{\prime \prime} \mathrm{E}$ (A. Abramov); $20^{7} \sigma^{7},+$ (ZISP), Cao Bang Province, Nguen Binh Distr., Quang Ranh vill., V.1998 (N.L. Orlov); $\sigma^{7}$ (ZISP), $40 \mathrm{~km} \mathrm{NE}$ of Thai Nguen, 800 m, 30.X.1962 (O.N. Kabakov); $\odot^{7}$, + , same data except $30\left(\mathrm{O}^{7}\right)$ or $50(9) \mathrm{km} \mathrm{NE}$..., $300 \mathrm{~m}$, 8.III.1963. — Genitalia examined in four males and one female.

DIAGNOSIS. Hardly different from the nominotypical subspecies in the following points: Head without anterior black spot, posterior black spot rather small, subcordate, anteriorly truncate or slightly concave, or long hourglass, extended toward and reaching pronotum; pronotum mostly with black median stripe not or slightly wider apically than basally, sometimes interrupted or entirely black. Pronotum cordate, broadest not quite a third from apex, base and apex subequally wide, sides well rounded, distinctly sinuate in front of basal angles. Elytra slightly shorter and wider apically than basally; ridges convex and narrow, mostly narrower than intervals; these with shorter and sparser longitudinal carinules.

REDESCRIPTION. Body mostly macropterous. BL 10.5$18 \mathrm{~mm}$ (14.5-16.5 mm in specimens from Vietnam). Dorsal pattern as in Figs 11-13, pale apical margin often broadened at outer angles, being reduced to a small, preapical, sublateral spot in melanistic forms (Figs 11-12).

Pronotum cordate, as wide as or barely wider than long, sides subsinuate a fifth from base and rounded in front. Base and apex truncate, basal angles mostly right, blunt or slightly pointed; apical angles as in the nominotypical subspecies.

Abdomen: Tergite VII in female with dense apical setae, 17-23, sometimes up to 30 , in number (Table 1).

Aedeagus (Figs 24-25, 37) same as in the nominotypical subspecies except that internal sac in dorso-apical view has basal bulb indistinctly sinuate at basal margin.

GEOGRAPHIC DISTRIBUTION. China (supposedly, except in the south): Gansu, Sichuan, Jiangxi, 'Manchuria'; Korea; Japan south to Satsunan Islands; northeastern Vietnam. The only record in Hong Kong is based on single specimen [Aston, 2016].

COMMENTS. Melanistic specimens from Cao Bang Province, Vietnam, are distinctive (Fig. 11) in having the pronotum, tibiae, tarsi, antennomeres $2-5$ infuscated to black and the scape partly so; some of these specimens have a minute, vague, pale pronotal spot.

While normally developed wings being reported by Habu [1967] for the species, some local populations from China and northern Vietnam have been found to be at least polymorphic in this characters. For instance, all the three examined specimens from Gansu are apterous.

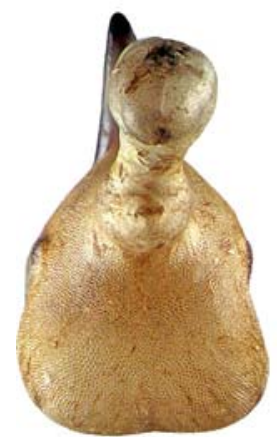

34

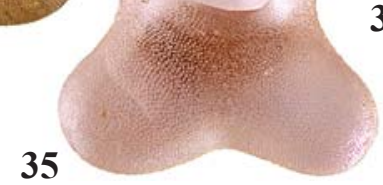

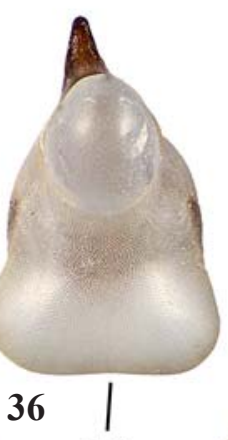

$b b$
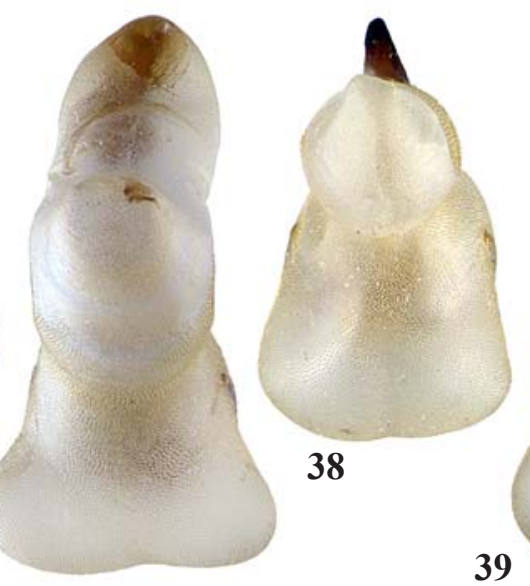

39

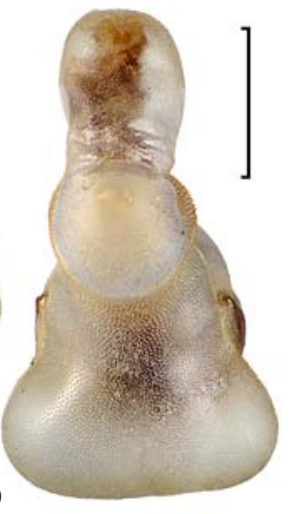

Figs 34-39. Median lobe of aedeagus with everted and inflated internal sac, dorso-apical aspect: 34 - Stenaptinus o. indicus; 35 - S.

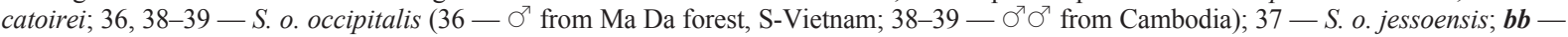
basal bulb. Scale bar: $1 \mathrm{~mm}$.

Рис. 34-39. Средняя доля эдеагуса с вывернутым и надутым внутренним мешком, дорзо-апикально: 34 - Stenaptinus o. indicus;

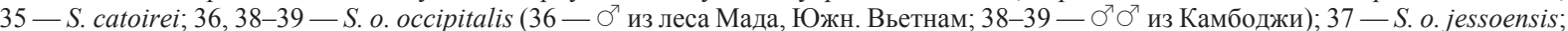
$\boldsymbol{b} \boldsymbol{b}$ - базальный пузырь. Масштаб: 1 мм. 


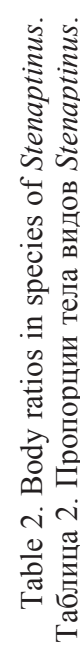

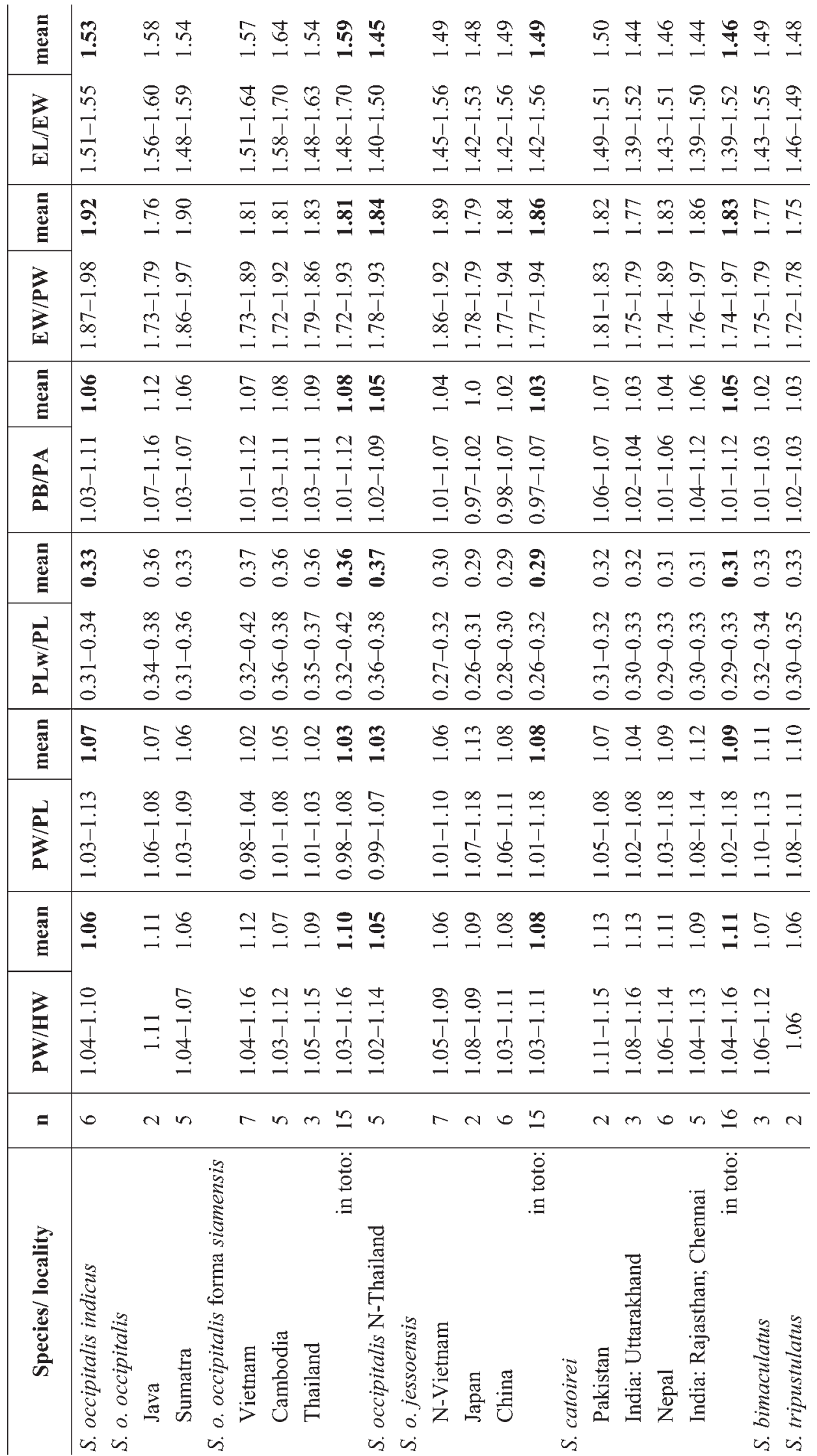




\section{[2. Stenaptinus catoirei (Dejean, 1825)]} Figs 15-19, 31-32, 35.

Dejean, 1825: 301 (Brachinus; 'Bengale'); Chaudoir, 1876: 24 (Pheropsophus); Bates, 1892: 391; Arrow, 1901: 202; Andrewes, 1924c: 55; 1930: 271; Hrdlička, 2017: 479; Venugopal et Thomas, 2019: 70. - chaudoiri Arrow, 1901: 203 (Pheropsophus; Nepal); Andrewes, 1924c: 56; Hrdlička, 2017: 479; Venugopal et Thomas, 2019: 71. — sobrinus Dejean, 1826: 462 (Brachinus; Indes Orientales); Chaudoir, 1876: 25 (Pheropsophus); Arrow, 1901: 202; Hrdlička, 2017: 480; Felix et al., 2012: 77; Venugopal et Thomas, 2019: 81. — desbordesi Maindron, 1899: 16 (Pheropsophus; Pakistan). - hilaris (non Fabricius, 1798): Chaudoir, 1876: 25; Bates, 1892: 391; Hrdlička, 2017: 479; Andrewes, 1921: 159; 1924c: 55. — malaisei Landin, 1955: 470 (Pheropsophus; N Myanmar), syn.n. - ?africanus Dejean, 1825: 303 (Brachinus; Tripoli, Barbarie); Chaudoir, 1876: 22 (Pheropsophus); Bedel, 1914: 310; Felix, 2009: 67; Hrdlička, 2017: 479. — aegyptiacus Mannerheim, 1837: 38 (Brachinus; Egypt). — ?arabicus Arrow, 1901: 201 (Pheropsophus; Arabia); Hrdlička, 2017: 479. — persicus Mandl, 1963: (Pheropsophus africanus ssp., Iran).

MATERIAL. ơ, + (MPSU), Pakistan, Muzaffargarh, 1.XI25.XII.1994 (V. Syomin); ア , 2 + (SIEE), India, Rajasthan, 30 km SW of Bikaner, Thar Desert, 3.VII.2005 (A. Sokolov); O’, o (SIEE), Madras env., Manapakkam, 15-30.VII.1999; + (SIEE), Uttarakhand, Uttarkashi env., Bhagirathi river, flood-land Pinus-forest, 19. IV.2012 (I. Melnik); フ , 9 (SIEE), same locality, except for Haridwar Distr. Ganga River, floodland forest, $29^{\circ} 58^{\prime} 09^{\prime \prime} \mathrm{N} / 78^{\circ} 12^{\prime} 16^{\prime \prime} \mathrm{E}-28^{\circ} 58^{\prime} 39^{\prime \prime} \mathrm{N}$ $78^{\circ} 12^{\prime} 54^{\prime \prime}, \mathrm{h}=330 \mathrm{~m}, 14-16$. IV.2012 (I. Melnik); ᄋ (MPSU), Nepal, Pokhara, h=1200 m, 20.V.1996 (M. Chernyakhovsky); O', 2 우 (MPSU), same locality, lake shore, 10-17.V.1996 (P. Udovichenko); + (MPSU), Chetwan National Park, env. Sauratkha vill., floodland meadow, 27.IX.1998 (E. Koblik); ㅇ (MPSU), env. Katmandu, Rhanibam Mt. Ridge, Nagarjun Mt, 15.IV-5.V.1996 (P. Udovichenko).

REDESCRIPTION. Unnecessary here except as follows: aedeagus (Figs 31-32, 35) very similar to that of $S$. occipitalis, except only that basal bulb of internal sac is distinctly subdivided into lateral bulbs which more laterally projecting, with basal margin sinuate (vs. straight) in dorso-apical view.

GEOGRAPHIC DISTRIBUTION. Pakistan, India, including Andaman Islands, Sri Lanka, Nepal, Bangladesh, Myanmar, Socotra Is. Stenaptinus africanus and S. arabicus combined: North Africa from Morocco to Egypt, Sinai, Israel, Jordan, Saudi Arabia, Yemen, Iraq, Iran.

\section{[3. Stenaptinus bimaculatus (Linnaeus, 1771)]} Figs 14, 26, 33.

Linnaeus, 1771: 532 (Carabus); Fabricius, 1775: 243 (Ind. or.); Olivier, 1795: 65, 1808: pl.2, Figs 16 a-c (part.); Dejean, 1825: 299 (Brachinus); Chaudoir, 1876: 34 (Pheropsophus); Bates, 1886: 200; Andrewes, 1919: 120; 1921: 153; 1930: 271; Csiki, 1932 : 1598. — posticalis Arrow, 1901: 204 (Pheropsophus bimaculatus var.); Andrewes, 1919: 198.

MATERIAL. $3 \sigma^{7} \sigma^{7}$ (SIEE), Sri lanka, North-West Province, Marawilla, $7^{\circ} 24^{\prime} 50^{\prime \prime} \mathrm{N} / 79^{\circ} 48^{\prime} 57^{\prime \prime} \mathrm{E}, \mathrm{h}=10$ m, 25.XII.2012-1.I.2013 (I. Melnik).

REDESCRIPTION. Unnecessary here except as follows: aedeagus (Figs 26, 33) very distinctive due to internal sac robust, very gentle, almost straight, with gonopore dorsal, apical bulb minute, ventral convexity very short.

GEOGRAPHIC DISTRIBUTION. Southern India, Sri Lanka.

Aknowledgements. I am much obliged to Dr. Roman Dudko (SZM), Dr. Boris Kataev (ZISP), and Dr. Kirill Makarov (MPSU) for the loan of material under their care, and to Azadeh Taghavian-Azari (MNHN) for high-resolution images of the type of Pheropsophus siamensis. My sincere thanks also to Alexander Kompantsev (SIEE), Igor Melnik (Moscow), Dr. Alexander Prosvirov (The Moscow State
University) for donating specimens and to Dr. Alexey Abramov (ZISP) for this assistance in collecting beetles in Vietnam. This study was funded by the Presidium of the Russian academy of sciences, Program No.41 "Biodiversity of natural systems and biological resources of Russia".

\section{References}

Andrewes H.E. 1919. Notes on the types of Oriental Carabidae in the British Museum, and in the Hope Department of the Oxford University Museum // Trans. Ent. Soc. Lond. P.119-217.

Andrewes H.E. 1921. Notes on synonymy and on some types of Oriental Carabidae in various foreign collections // Trans. Ent. Soc. Lond. P.145-195.

Andrewes H.E. 1923. On the types of Carabidae described by Schmidt-Goebel in his Faunula Coleopterorum Birmaniae // Trans. Ent. Soc. Lond. P.1-63.

Andrewes H.E. 1924a. A list of Carabidae from Macao, South China, with a description of a new species and biological notes // Ann. Mag. Nat. Hist. London. Ser.9. Vol.13. P.466-472.

Andrewes H.E. 1924b. Papers on Oriental Carabidae. - 14 // Ann. Mag. Nat. Hist. London. Ser.9. Vol.14. P.585-593.

Andrewes H.E. 1924c. Mission Guy Babault dans les provinces centrales de l'Inde et dans la région occidentale de l'Himalaya 1914. Résultats scientifiques. Insectes Coleopteres, Carabidae. Paris. P.1-123. Pl.1-4.

Andrewes H.E. 1930. Catalogue of Indian Insects. Calcutta: Government of India. XXII $+389+4$ pp.

Andrewes H.E. 1931. On the Carabidae of Mt. Kinabalu // Journal Feder. Malay Mus. Vol.16. Pt.3-4. P.431-485.

Andrewes H.E. 1933. A Catalogue of the Carabidae of Sumatra // Tidschr. Entomol. Jg.76. S. 319-382.

Arrow G.J. 1901. The carabid genus Pheropsophus: Notes and descriptions of new species // Trans. Ent. Soc. Lond. P.193-206.

Aston P. 2016. Catalogue and Bibliography of the Hong Kong Carabidae Latreille, 1802 (Coleoptera: Adephaga), with notes on the historic boundaries of Hong Kong as related to zoological collections // Zootaxa Vol.4121. No.3. P.201-257.

Bates H.W. 1886. On the geodephagous Coleoptera collected by Mr. George Levis in Ceylon // Ann. Mag. Nat. Hist. London. Ser.5. Vol.17. P.199-212.

Bates H.W. 1889. Contributions a la faune Indo-Chinoise. $3^{\mathrm{e}}$ Mémoire. Carabidae // Ann. Soc. Ent. France. $6^{\text {e }}$ sér. T. 9. P. 261-286.

Bates H.W. 1892. Viaggio di Leonardo Fea in Birmania e regione vicine. XLIV. List of the Carabidae // Ann. Mus. Stor. Nat. Genova. Ser. 2. Vol.12. No.32. P.267-428.

Bedel L. 1914 (1895-1914). Catalogue raisonnés des Coléopterès du nord de l'Afrique (Maroc, Algérie, Tunesie et Tripolitanie) avec notes sur la faune des iles Canaries et de Madère. Paris. 402 pp.

Britton E.B. 1948. Coleoptera: Cicindelidae and Carabidae / Expedition to South-west Arabia 1937-8. Vol.1. London: British Museum (Natural History). P.87-125.

Chaudoir M. 1843. Carabiques nouveaux decrits... // Bull. Soc. Nat. Mosc. T.16. N.4. P.671-791.

Chaudoir M. 1850. Mémoire sur la famille des Carabiques, 2 // Bull. Soc. Nat. Mosc. T.23. N.1. P.1-85.

Chaudoir M. 1876. Monographie des Brachynides // Ann. Soc. Ent. Belg. T.19. P.11-104.

Csiki E.v. 1932. Carabidae. Harpalinae VII-VIII // W. Junk, S. Schenkling (Eds). Coleopterorum Catalogus. Vol.3. Pt.124. Berlin: W. Junk pbls. S.1279-1598.

Dejean P.F.M.A. 1825. Species général des Coléoptères de la Collection de M. le Comte Dejean. T.1. Paris. XXX+463 pp.

Dejean P.F.M.A. 1826. Species general des coleopteres de la collection de M. le comte Dejean. Vol.2. VIII+501 pp.

Dupuis P. 1912. H. Sauter's Formosa ausbeute Carabidae (2me contribution) // Ann. Soc. Ent. Belg. T.56. P.308-338.

Dupuis P. 1913. H. Sauter's Formosa ausbeute Carabidae (3e contribution) // Ann. Soc. Ent. Belg. T.57. P.81-87.

Dupuis P. 1914. H. Sauter's Formosa ausbeute Carabidae // Ann. Soc. Ent. Belg. T.57. P.418-425. 
Fabricius J.C. 1775. Systema entomologiae, sistens insectorum classes, ordines, genera, species, adiectis synonymis, locis, descriptionibus, observationibus. Flensburgi et Lipsiae: Kortii. xxxii $+832 \mathrm{pp}$.

Fabricius J.C. 1792. Entomologia systematica emendata et aucta, secundum classes, ordines, genera, species adjectis synonimis, locis, observationibus, descriptionibus. T.1. Pt.1. Hafniae: C.G. Proft. $x x+330$ pp.

Fedorenko D.N. 2020. Stenaptinus (Coleoptera: Carabidae: Brachininae) of Vietnam. Note $1 / /$ Russian Entomol. J. Vol.29. No.4. P.361-376. doi: 10.15298/rusentj.29.4.03.

Felix R.F.F.L. 2009. Order Coleoptera, family Carabidae // Arthropod fauna of the UAE. Vol.2. P.66-141.

Felix R.F.F.L., Farkac J., Suleiman A.S. 2012. Annotated checklist of the Carabidae of the Socotra Archipelago // Acta Mus. Nat. Pragae. Vol.2. Suppl.2. P.75-106.

Frank J.H., Erwin T.L., Hemenway R.C. 2009. Economically Beneficial Ground Beetles. The specialized predators Pheropsophus aequinoctialis (L.) and Stenaptinus jessoensis (Morawitz): Their laboratory behavior and descriptions of immature stages (Coleoptera, Carabidae, Brachininae) // ZooKeys. Vol.14. P.1-36.

Habu A. 1967. Carabidae Truncatipenne group (Insecta, Coleoptera). Fauna Japonica. Biogeographical Society of Japan. Tokyo. XIV +338 pp. 27 pl.

Habu A. 1984. Revised and supplementary notes on and descriptions of the Truncatipennes group of Japan (IV) (Coleoptera, Carabidae) // Ent. Rev. Japan. Vol.39. No.2. P.101-138.

Hrdlička J. 2015. A contribution to the tribe Brachinini (Coleoptera: Carabidae) - V. Two new species of the genus Pheropsophus from the Australian Region // Folia Heyrovsk. Ser.A. Vol.22. Nos.2-4. P.21-25.

Hrdlička J. 2017. Brachininae // I. Löbl, A. Smetana (eds.). Catalogue of Palearctic Coleoptera. Vol.1. Archostemata - Myxophaga - Adephaga. Stenstrup: Appolo Books. P.471-480.

Jedlička A. 1935. Pheropsophus nigerrimus sp. n. // Časopis Čs. spol. Ent. Vol.32. P.136

Jedlička A. 1964. Monographie der Truncatipennen aus Ostasien. Lebiinae - Odacanthinae - Brachininae (Coleoptera, Carabidae) // Ent. Abhandl. Mus. Dresden, Dresden. [1963-1964]. Bd.28. Nr.7. S.305-579.
Landin B.-O. 1955. Entomological results from the Swedish expedition 1934 to Burma and British India. Coleoptera: Carabidae collected by René Malaise // Ark. Zool. Bd.8. No.3. P.399-472.

Lassalle B., Schnell R. 2019. Nouvelles espèces des genres Pheropsophus et Lesticus des Philippines // Faunitaxys. Vol.7. No.20. P.1-5.

Lesne P. 1904. Famille des Carabides // Pavie A. Mission Pavie IndoChine 1879-1895. Études diverses. III. Recherches sur l'histoire naturelle de 1'Indo-Chine orientale par Auguste Pavie. Paris: E. Leroux. P.62-81.

Linnaeus C., von. 1771. Mantissa plantarum Altera. Generrum editionis VI. \& specierum editionis II. Regni animalis. Appendix. Holmiae: Impensis Direct. Laurentii Salvis. 588 pp.

Lorenz W. 2005. Systematic list of extant ground beetles of the world (Insecta Coleoptera "Geadephaga": Trachypachidae and Carabidae incl. Paussinae, Cicindelinae, Rhysodinae). 2nd ed. Tutzing. $530 \mathrm{pp}$.

Macleay W.S. 1825. Annulosa Javanica, or, An attempt ... London. P.I-XII, 1-50.

Mandl K. 1963. Ergebnisse der Osterreichischer Iran-Expedition 1949/50, Carabidae (Col.). Copleoptera IX. Teil // Sitzungsb. Kaiser. Akad. Wiss. Wien, Math.-naturw. Klasse (Abt.I). Bd.172. S.179-192.

Mannerheim C.G. von. 1837. Mémoire sur quelques genres et espèces de carabiques // Bull. Soc. Nat. Mosc. T.10. No.2. P.3-49.

Morawitz A. 1862. Vorläufige Diagnosen neuer Carabiciden aus Hakodade // Mélang. Biol., Bull. Acad. Sci. St.-Pétersb. Vol.4. S.237-247.

Olivier G.A. 1795. Entomologie, ou Histoire Naturelle des insectes, avec leur charactères génériques et spécifiques, leur descriptions, leur synonymie et leur figure enluminée. Coléoptères, T.3. No.35. Carabe. Carabus. P.1-116, I-XXVIII.

Olivier G.A. 1808. Entomologie, ou Histoire Naturelle des insectes, avec leur charactères génériques et spécifiques, leur descriptions, leur synonymie et leur figure enluminée. Coléoptères, T.7. Planches. - Genres 1 a 65. No.35. Carabe. Carabus. P1.1-14. Schmidt-Göbel H.M. 1846. Faunula Coleopterorum Birmaniae, adjectis nonnulis Bengaliae indigenis. P.I-VIII, 1-94, P1.I-III.

Venugopal A., Thomas S. 2019. Bombardier beetles of the genus Pheropsophus Solier 1833 (Carabidae: Brachininae: Brachinini) from Indian subcontinent // Zootaxa. Vol.4608. No.1. P.65-89. 